\title{
Research Progress on Plant Selection of Roof Greening
}

\author{
Shuang Liu+ ${ }^{*}$, Chang-Cun Yuan + ,Ting Xuan and Zi-Ya Chen
}

Life Science and Technology School, Lingnan Normal University, Zhanjiang, 524048, China liushuangaaa@163.com,yuanchangchun@163.com,982088575@qq.com, 527722629@qq.com

+The author contributed equally to this work *For correspondence: liushuangaaa@163.com

Keywords: roof greening, plant selection, research progress

Abstract: Roof greening is an important part of urban garden, which has lots of irreplaceable function and benefits. As the development of city construction, roof greening has become an indispensable part of people's life and become the focus of attention in city. Plants as one of the important factors in roof greening, which research on its growing intensify in recent years. The text study on the research progress on plant selection of roof greening, and expectation its research focus and direction.

\section{Introduction}

Roof greening is build garden and planting trees flowers on the roof, balcony or large artificial rockery of all kinds of buildings, structures, bridges, etc. which could combining architectural art and greening. With the development of social economy, roof greening has become today's real estate industry and urban greening projects a big trend. Roof greening can achieve good effect, mainly depends on the choice of plant materials and their growth, choice of plant materials only adapted to the ecological environment of the roof can achieve good growth ideal greening effect[1].

\section{Research Progress on Plant Selection of Roof Greening in Europe}

Europe always in the choice of plant materials research frontier in the world. In the 19th century, Germany began to explore building large areas of vegetation change, and further study of the roof greening plant selection, planting technology and other technology [2]. Fisher was studied the resistance of Sedum album,Ajuga reptans cv,Delosperma, Penstemon campanulatus in 1987[3]. Some scholars studied the thin soil layer under the condition of plant cold hardiness and drought resistance and selected 11 kinds plants of Sedum L. and various plants of Semper vivium[4]. 
Scientists at Madrid university and Berlin university of common findings that Poa pratensis L., Sedum leucocarpum, and Bryophyte has the strong adaptability of roof greening[5]. British scientists screened perennial drought-resistant plant in semi-intensive roof greening which suitable for application in Sheffield[6]. British scholars study on drought resistance of Sedum L.in 2005, the results showed that Sedum $L$. is the preferred thin layer roof greening plants on account of it can endure extreme drought conditions[7]. Scientists of Czech Republic and Hungary had chosen kinds of plant of Sedum L., Semper vivium, Poa апnиa L., Bryophyte after study cold resistance and drought resistance on plant applications in roof greening[8].

\section{Research Progress on Plant Selection of Roof Greening in America}

America began the development of roof greening later, and has achieved rapid development with imitate European countries on the basis of roof greening. Chicago carried out garden experiment at the town hall building roof, plant selection conclude Sedum L., Mucuna birdwoodiana, and shrub. Selected 1200 kinds of plants conclude Sedum L., Eragrostis Beauv., Penstemon campanulatus, and Verbena hybrida Voss, etc. in 2002[9].

\section{Research Progress on Plant Selection of Roof Greening in Asia}

Japan is one of the earlier development of roof greening in Asia. Nowadays, nearly 40 various plants of Sedum L. used in roof greening in Japan[10]. Sendo find that Thymus Linn. is the best plant for roof greening in Kobe[11]. In recent years, Japan developed mainly trees of roof greening planting technology of pure forest in order to meet the needs of different functions[12]. In Turkey, Oztan and Y.Arslan tested some evergreen, low, covering force strong pulpy plants and screened 27 kinds of plants can be used for the local construction of greening plants conclude Sedum L., S. fortunei Vis., Euphorbia L. and semper vivium[13].

\section{Research Progress on Plant Selection of Roof Greening in China}

Roof greening research starts later in China, and began to study the roof greening and its construction technology in the 1960s. The main choice for the purpose of vegetable, melon and fruit production and plant house green[14]. Early 21st century, roof greening began having its own development model in China, but the research relative lag on the choice of plant materials and adaptability compared with the developed countries.

The landscape science research institute of Beijing selected Sedum.lineare to suitable for roof 
greening which could cold-resistant and water conservation[15]. Wei Chang-huang and Jun Qin studied on Sedu.lineare, Sedum.Sarmentosum, Sedum.makinoi, Sedum.emarginatum and Sedum.hybridum, selected three kinds of plants suitable for roof greening in Shanghai conclude Sedu.lineare, Sedum.emarginatum and Sedum.Sarmentosum through comparative analysis[16].

Zhao Ding-guo and Kuang Xiao-man tracked experiment on over-winter of Sedum.lineare in Beijing, the results show that Sedum.lineare shows good adaptability on over-winter and could apply to roof greening[17]. Liu Wei-dong researched on plant application of roof greening in Chengdu, and using the five-point scale evaluation method to evaluated growth situation and environmental suitability of plants[18]. Huang Min-ye studied the drought resisting of Sedum. Sarmentosum, Sedum. Prasinopetalum and Portulaca grandiflora, results showed that the drought resisting of Portulaca grandiflora relatively weaker and not suitable for large area applications[19]. Wuhan botanical garden academy of sciences selected the appropriate application of roof greening plants in Wuhan after botanizing and analysis of the data[20]. Wang Li-yuan studied the suitability and matrix formulation of four kinds of roof greening plants in Guangzhou[21]. Zhang Min selected the experimental research on trees and shrubs of roof greening in Jinan, and proposed different plant landscape design method[22]. Cultivation experiment was carried out on the roof natural environment and two years of plant seedlings as materials by Ren Shuai, selected plant materials suitable for roof greening in Shanxi[23]. Jian Shu-guang had carried on the extensive investigation and analysis research on natural plant's growth in different environment roof in Guangzhou, recommended for 12 kinds of plants with good roof garden potential[24]. Li Yan-bing screened eight kinds of roof greening plants and different soil and evaluated the heat resistance of plant in Fuzhou[25]. Ren Xue studied the amount and type of roof greening plants and analyzed the stress tolerance of three kinds of plants in Hangzhou[26].

\section{Expectation}

Roof greening is an important part of urban garden which has lots of irreplaceable function and benefits. Nowadays, roof greening has been in the direction of the comprehensive function transformation. Plant as an important component of roof greening, its research and application could determine the direction of roof greening directly. So more and more plant species used in roof greening is required in plant selection. Choose adaptable, high appreciation, low maintenance and low-energy plant on applied to the roof and create a landscape, ecological roof environment will 
become research interests.

\section{Acknowledgements}

This research is supported by National Spark Program of China (Grants: 2013GA780074) and Collaborative Innovation Center Project of Lingnan Normal University (grant no. CIL1503)

\section{References:}

[1] Jing Heng. Study on the Selection and Adaptability of Plant Materials for Roof Greening in ZhengZhou [D]. Henan Agricultural University.2010

[2] Rong An. Large Area Vegetation of Building Environment in German Cities. [J] World Architecture.2002.(12)59-62

[3] Fisher. Greening of outdoor surfaces on a thin layer of expanded Clay.[German].Deutscher Gartenbau.1987.(41)

[4] Gomez,Tortosa L. Plants Species In Green Roof.[Spanish]. Agriculture Revista Agropecuana.1996.(12)

[5] PANAyiotis NeKTARios, et al. Comparison of different roof garden substrates and their impact on plant growth [J]. Acta Hort.2004(643)311-313

[6] Dunnett,N and Nolan,A. The effect of substrate depth and supplemental watering on the growth of nine herbaceous perennials in a Semi-estensive green roofs[J]. Acta Hort.2001(643) 305-309

[7] VANWOERT NICHOLAUS D. et al. Watering regime and green roof substrate design affect Sedum plant growth[J]. Hort Science.2005(40) 659-664.

[8] Kutkova, T.Herbaceous. Plants for sites with extreme conditions in landscape architecture.[Czech].Acta Universitais Agriculturae.1990(5)

[9] KEMER F et al. Plant species suitable for establishing living roofs in 52 Hungary.I.Sedum spp.[J].Acta-Botanica-Hungarica.1999-2000.

[10] YinLi-feng, Li Shu-hua. Roof Garden Technology in Japan [J]. Chinese Landscape Architecture.2005(5) 62-66

[11]Sendo, et al. Faculty of Agriculture[A].Abustr-acts27th International Horthcultural Congress and Exhibitotion [C].2006:433

[12]Zhang Jie. Research on the light roof greening technology in Shanghai [D].Qingdao Agricultural University.2007

[13] Oztan,Arslan. Research Carried Out To Determine The Species Of Succulent Plants That Can 
Be Grown In The Ecological Conditions Of Central Anatolia Region And The Possibilities Of Their Use As Ground Cover From The Landscape Architectural Point Of View[M].Turkish:Doga.Turk Tanmve Ormancilik Dergisi.1993

[14] Zi Zhao-yi. Brief Discussion about Roof Greening [J]. Sci-Tech Information Development \& Economy.2003 (5) 117-118

[15] Zhou Wei-wei, Wang Yan. Some Views on Urban Roof Greening in Beijing [J]. Journal of Chinese Urban Forestry.2006(4) 35-37

[16]Huang Wei-chang et al. Study On the Application of Sedums on Roof Garden in Shanghai [J]. Journal of Anhui Agi.Sci.2005 (6) 1041-1043

[17] Zhao Ding-guo et al. The beginning of the experiment report on sedum lineare in Beijing [F]. Grassland and Turf. 2005(1) 71-72

[18] Liu Wei-dong. Studies on Ecological Effect and Selection of Roof Greening Plants in Chengdu City [D] Sichuan Agricultural University.2006

[19] Huang Min-ye. Research on cold hardiness of roof greening plant [J]. Jilin Agricultural. 2010(07) 164

[20] $\mathrm{Xu}$ Jing-ping. The Resistance of Greening Woody Plants. [D] Agricultural University of Hebei.2011

[21] Wang Li-yuan. The Evaluation of Several Green Roof Plants Suitability and Research of That Matrix Formula in Guangzhou Area [D]. Gansu Agricultural University.2011

[22] Zhang Min. The Plants Selection of Roof Greening and Application Study in Jinan[D]. Shandong Jianzhu University.2012

[23] Ren Shuai. Adaptability research of Common Green plants for Roof Greening[D]. Shanxi Agricultural University.2013

[24] Jian Shu-guang et al. Different environment roof plant diversity analysis of natural growth in Guangzhou [J] Ecology and Environment.2005(14) 75 80

[25] Li Yan-bing. Selection of Roof Greening Plants and Heat Resistance Assessment in Fuzhou [D]. Fujian Agriculture and Forestry University.2009

[26] Ren Xue. Study on the Survey and Resistance of Plant Materials for Roof Greening in Hangzhou [D]. Zhejiang Agriculture and Forestry University.2012 